\title{
アンビュラトリ血圧計測における生物行動的要因
}

\author{
札幌医科大学心理学教室 澤田 幸展
}

\section{Biobehavioral factors in ambulatory blood pressure monitoring}

\author{
Yukihiro SAWADA \\ Department of Psychology, Sapporo Medical University, \\ South 1 West 17, Chuo-ku, Sapporo, 060-8556, Japan
}

\begin{abstract}
In the present review, biobehavioral factors in ambulatory blood pressure (BP) monitoring were assessed from a psychophysiological standpoint. First, the validity of ambulatory BP was investigated, and problems with measurement errors were clarified. Second, behavioral diary and actimetry were assessed in terms of the degree to which they enable us to interpret BP variations, and some demerits, especially regarding the reactive nature of the behavioral diary, were pointed out. Third, 24-hour long-term BP variations were interpreted as diurnal variations rather than circadian rhythm. Fourth, category/option and episode were advocated as two sorts of conceptual frames to analyze a diversity of BP variations, whether long- or short-term, and some examples from typical studies were presented using the frames of reference, underlying the influence of biobehavioral factors. Fifth, some intriguing ambulatory studies using parameters besides BP were appraised, and finally, the promising nature of ambulatory psychophysiology was discussed.
\end{abstract}

Key words: ambulatory blood pressure monitoring, blood pressure variations, biobehavioral factors, behavioral diary, ambulatory psychophysiology

【要 約】本評論では, アンビュラトリ血圧(BP)計測における生物行動的要因が，心理生理学的視点から 評価された，第 1 に，アンビュラトリBPの妥当性が評価され, 計測誤差とかかわる問題が明確化された. 第 2 に，行動日誌および体動計測が，BP変動の解釈をどの程度可能にさせるかという観点から評価され, いくつかの短所(とくに, 行動日誌の反応性を高める性質) が指摘された. 第 3 に, 24 時間長期 BP変動が, 概日リズムよりは日内変動であると解釈された。第 4 に, カテゴリー/オプションおよびエピソードが, 長 期的であれ短期的であれ，多様な BP变動を分析するための 2 種類の概念的枠組みとして提唱され, 典型的 研究からのいくつかの例が, 生物行動的要因の影響を強調しながら, これらの参照枠に従って提示された. 第 5 に, BP以外のパラメー夕を用いた, いくつかの興味深いアンビュラトリ研究が評価され, そして最後 に,アンビュラトリ心理生理学の有望性が議論された。

\section{はじめに}

血圧 (blood pressure: BP)は, 心臓血管系における 基本的かつ最重要なパラメータの一つである。し たがって，基礎と臨床を問わず，また，医学・生理 学はもとより, 心理生理学や運動生理学, さらに は, 健康科学に至るまで, BPの計測される機会は
多い、診察室や実験室で, 医師や看護婦, あるい は, 実験者の手によって, 随時 BP としてその値が 求められる。

ところで, 比較的古くから知られていたことであ るが(Chesney, 1984), 診察室で医師ないし看護婦に よって計られた BPは，自宅で得られたものよりも，

1999.8.4 受稿, 1999.11.1 受理 
かなり高く出る傾向がある，つまり，もっとも一 般的な診察室での随時 BPは, 典型的な值と言える のか, 大いに疑わしいところがある。したがって, 診察室での随時 BPを重要な基準として, 高血圧の 診断や治療を進めてよいのか, 議論がわき起こる のも当然であろう. とくに，高血圧の大多数を占 める軽症高血圧 (拡張期 BP が 90〜 105 mm Hg) の場 合, 日常生活場面では大半が正常 BP範囲, といっ たことも大いにあり得る、診察室で白衣の医師と 対面し，BPを計測されるといういわばテスト場面 は，それ自体がストレスに満ちており，患者によっ ては一過性の血圧上昇を呈しかねないわけである。 この現象は, 今日, 白衣性高血圧と呼ばれて, 話題 になっている (Pickering, James, Boddie, Harshfield, Blank, \& Laragh, 1988).

そこで, 1 日 24 時間の全体を通じた, 日常生活場 面でのBP変化を押さえたいとするニーズが，かな り早くから根強く存在することとなった。 小型か つ軽量で, 携帯可能な—したがって, 日常生活場 面の自由行動下で計測可能な, いわゆるアンビュ ラトリ (ambulatory) BP 装置は, こうした医学・生 理学的ニーズに答えるべく, 開発が進められてき たものである. そして, 医学の臨床家や研究者が アンビュラトリBP装置を手にした現在, その用途 は高血圧の確定診断にとどまらず，降圧剤の効果 判定や予後の判断, さらには, 高血圧の発症過程 に関する検討など, 多方面に及んできている(Mancia, Omboni, \& Parati, 1997; Parati, Pomidossi, Albini, Malaspina, \& Mancia, 1987).

さて, 本評論の立場であるが, アンビュラトリ $\mathrm{BP}$ 計測とかかわる上述のような医学・生理学的問 題意識の重要性は認めながらも, これらを直接に 議論の対象とするものではない. むしろ, 日常生 活場面で実施されるアンビュラトリ計測は, 特定の 実験室的セッティングで行われる短期間の計測よ りも，当該個人にとっていっそう代表的であると の基本的な認識に立って, その可能性を心理生理 学的に探ろうとするものである。 その際, 当然な がらアンビュラトリな場面では, 実験室的セッティ ングと異なる特有の難しい点がある。たとえば, 計 測精度をどうやって確保するかとか, 日内変動の 問題をデータの解釈にどう折り込むか, といった
点である，また，アンビュラトリな場面では，独 特な工夫も求められる.たとえば, 日誌による行 動のチェックであり，いっそう客観的な方法によ る体動のチェックである。こうした基礎固めの上 に立って, 被験者の体質的遺伝ないし性別・人種 などといった，背景をなす生物的要因や，当人の 日誌などから捉えられる各種の行動的要因が，ア ンビュラトリ・データのバラッキにどう影響して いるかを読み解いて行くことが, 心理生理学的接 近法に他ならない。 ちなみに, アンビュラトリ計 測の標的としてBPが選択されたのは，こうした視 点からみても, 検討し得るデー夕が比較的よく蓄 積されてきたことによる，なお，こうしたアンビュ ラトリ心理生理学の視点が, 翻って, アンビュラ トリBP計測における医学・生理学的問題意識を深 める上で少なから貢献をなすことは, 期待して よいであろう。

\section{BP 計測精度}

アンビュラトリBP計測装置の開発は, 1960 年代 前半から直接法と間接法の双方で始まり, 前者 (動 脈管に直接カニューレを挿入)の代表と言われる オックスフォード法は, 1969 年にその姿を現した (Bevan, Honour, \& Scott, 1969). 一方, 後者は, 患 者ないし被験者が, 自らカフを加圧しなければ計 測が始まらない半自動型と,こうした必要のない 全自動型に大別され (Shapiro, Jamner, Lane, Light, Myrtek, Sawada, \& Steptoe, 1996), 聴診法 (RivaRocci 法)による全自動の第 1 号が世に問われたの は, 1964 年であった (Richardson, Honour, Fenton, Stott, \& Pickering, 1964). したがって, アンビュラ トリ BP 計測装置は, Holter 型の心電計と同程度の 歴史を有することになる。本評論では，アンビュ ラトリ BP計測装置といえば，間接法によるものを 指すこととする.

さて,アンビュラトリBP計測装置を通覧した最 新のまとめによれば (O’Brien, Atkins, \& Staessen, 1995), この時点で 43 種 (業者数は 31 社)のものが 出回っている.ただし，これらの内で，米国医療 機器改善協会, 並びに, 英国高血圧学会の推奨す る基準を一定水準以上で共に満たしたアンビュラ トリBP 計測装置は，9種類に過ぎないという。そ 
の中には，さまざまな論文に顔を出す Spacelabsの シリーズや, 我が国の Takedaのシリーズが含まれ ている. Fig. 1 は, Spacelabs シリーズ (90202および 90207)の計測精度について, 直接法と比較したも のである (Groppelli, Omboni, Parati, \& Mancia, 1992). 被験者は 40 歳前後の男女高血圧症患者 9 名 であり, Spacelabs シリーズでの計測は, 早朝 6 時 から真夜中までが 10 分毎, 真夜中から翌朝 6 時ま でが20分毎，であった。なお，Fig.1のデー夕は， 平均 BP〔〔拡張期 BP + (収縮期 BP - 拡張期 BP) / $3 」$ て概算】の 1 時間毎平均值を示している. まと めの幅が 1 時間毎と大きいため, アンビュラトリ平 均 BP(点線) は, 行動的要因による細かな変化を十 分に反映したものとはいえないが, 直接法 (実線) とかなりよく対応していることが見て取れよう. 夜 22 時前後から朝 6 時前後までの, 平均 BPが下降 している時間帯で, 被験者達は睡眠を取っている. この間, アンビュラトリ平均 BP が直接法でのそれ よりも一貫して高めに出ている点について, Groppelli et al. (1992) は何ら言及していないが, データ 的にいえば, 収縮期 BPに影響されたところが大で ある。

ちなみに，上記両基準の改定版は, White, Berson, Robbins, Jamieson, Prisant, Roccella, \& Sheps (1993)に紹介されているが, それによると, BP計測 一般に適用すべきこととして，たとえば，標準的な

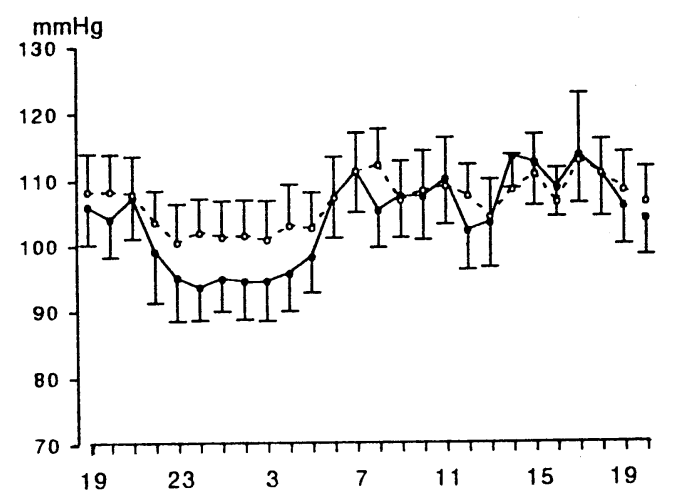

Fig. 1 アンビュラトリ血圧計測装置 (点線: Spacelabs シリーズ)および直接法(実線)で得られた 24 時間平 均血圧変動の典型例. グラフ上の点および縦棒= 平均血圧の 1 時間毎平均值およびその標準誤差; グ ラフ右端のそれら $=24$ 時間全体の総合 (Groppelli et al., 1992 から転載).
BP 計測 (直接法または聴診法) と比べた計測誤差 が, 平均で $\pm 5 \mathrm{mmHg}$ 以内, 標準偏差で $8 \mathrm{mmHg}$ 以 内に収まっていなければならない.とくに, 聴診 法と比較するときは, 85 名以上の一それも, BP 水準や腕の太さがさまざまな被験者を必要とする. これに対し, 直接法との比較であれば, 被験者確 保の難しさを考慮して, 15 名以上の被験者を必要 とする,などのチェック項目が挙げられている.さ らに, アンビュラトリ BP 計測用の追加チェック項 目として, 臥位・座位・立位の三つの姿勢で, 精 度が検討されるべきである. 動作中や臨床的使用 に耐え得るかどうか, 確かめられるべきである。 カ フないし内蔵マイク位置のずれをチェックする意 味から, 24 時間計測の開始前と終了後の両時点に ついても, 20 名以上の被験者を用いて標準法と比 較し, $75 \%$ の計測例で平均 $\pm 5 \mathrm{mmHg}$ 以内の誤差 であるか否か確認すべきである，といった点が挙げ られている.

このように, アンビュラトリ BP計測の場合, そ の基本となる $\mathrm{BP}$ 計測一般でのチェック項目に加 え, アンビュラトリ BP 計測に特有のチェック項目 が専門機関から指定されている事実は，アンビュ ラトリBP計測がいかに多くの計測誤差要因を抱え 込む恐れがあるかを，如実に物語っている。その 意味で, アンビュラトリBP計測において，ある程 度までの計測誤差は避け難い (Staessen, Fagard, Thijs, \& Amery, 1995)。当然ながら, 日常生活場面 において直接法と比較検討すれば，アンビュラト リ BP 計測が少なからざるアーチファクトに見舞わ れている事実を，知らされることにもなる (West, Townend, Davies, Sheridan, Stallard, Davies, \& Littler, 1991).

ところで, 最近のアンビュラトリBP計測は, 計 測誤差対策も兼ねて, 聴診法よりは振動法を活用 する傾向にある(O’Brien et al., 1995).この振動法 では，上腕に巻かれたカフが加圧状態にあるとき， その直下に位置する血管の拍動が上腕周囲組織を 介してカフ内に伝達され，カフ圧に重畳した微小 な圧振動の生じることを利用する。つまり,この 微小圧振動の振幅変化から, BPを間接的に推定し ようとするものである. 本法の利点としては, 聴 診法と比べて, 費用的に安上がりで, アルゴリズ 
ムもさほど複雑でない. 騒音の多い環境でも使用 可能であり，コロトコフ音が消えないようなケー スでも拡張期 BP の值が決定できる, といったこと が挙げられる (Staessen et al., 1995)。ただし，カフ 圧に重冨した微小な圧振動は, 収縮期 BP より上か ら拡張期 BP より下まで, カフ圧の広い範囲で連続 的に認められるから,これら両 BPの決定は, 経験 的・統計的に得られたメーカー独自のアルゴリズ ムによっているのが現状である，また，運動中の 計測など, カフ圧にアーチファクト性の微小振動 が混入し易い状況では, 聴診法よりも精度の落ち ることがあり得る。したがって、アンビュラトリ BP 計測装置によっては, 聴診法と振動法を併用し て, 双方の読みを比較できるようにするとともに, 片方で読めない場合は他方で代用する，といった ものも存在する.

なお, Di Rienzo, Grassi, Pedotti, \& Mancia (1983) によれば, 24 時間にわたる平均 BP 水準は, 直接法 による 1 拍毎の連続計測であれ，60 分間隔のアン ビュラトリ BP計測であれ，ほとんど違わない。し かし, 標準偏差については, 15 分ないしそれ以上 間隔の開くアンビュラトリ計測だと, 1 拍毎連続計 測との差が大幅に拡大する, という。大半のアン ビュラトリBP計測装置は, 計測間隔が 15 分ない し 30 分 (夜間睡眠時はしばしば 60 分)であるから, $\mathrm{BP}$ の平均水準は正しく決定できるものの, 短期の 変動は推定に難が残る，と考えておくべきであろ う.このことと関連して, BP水準が高いと, その 変動も一般的に大きくなるから, 高齢者や高血圧 患者の場合, アンビュラトリ BP計測の精度は落ち る (Miller, Elam, Graney, \& Applegate, 1992), とい う点も念頭に置いておく方がよい.

最後に, 計測精度 (妥当性) の問題を離れ, 計測一 再計測再現性 (信頼性)について言えば, 平均 BP 水 準の場合, アンビュラトリ BPの方が診察室での聴 診法による BPよりも結果が良い(Conway \& Coats, 1989). 計測回数が圧倒的に多いからである.これ に対し，標準偏差に関して，アンビュラトリ BPの 再現性は期待できない. 標準偏差の大小を決める のは, 主として短期の BP 変動であり, それは行動 的要因によって左右されるところが大である(「生 物行動的要因」の節を参照). 行動的要因は, 計測
日によってその出現頻度およびパターンとも, 少 なからず変化するであろうから, 再現性が低く出 ても当然といえよう，以上のような議論から，ア ンビュラトリ BP 計測の大きな問題点の一つは, 計 測装置それ自体の精度という, 入り口のところに あることが分かるであろう。アンビュラトリ BP 計 測を試みる際は，何はさておいても，当該計測装 置の精度確認が求められる所以である。ちなみに, 市販されているアンビュラトリBP計測装置につい て, 装着状態などの具体的なイメージを得たけれ ば，栃久保 (1988; pp.58-62)を参照されたい.

\section{行動日誌・体動計測}

アンビュラトリBPは，それ自体を見ただけで は, 分析の難しい場合が少なくない.たとえば, あ る時点で読まれた収縮期 BP が $160 \mathrm{mmHg}$ であり, 直前回 15 分前の読みが $120 \mathrm{mmHg}$ であったとしよ う.この急激な BP 上昇が, 安静状態から急に階段 を駆け上がったことで生じたのか，それとも，誰 か見知らぬ人と会話を始めたことで誘発されたの かによって，意味する内容は相当に異なるはずで ある.つまり, 心理生理学的な視点に立てば, ア ンビュラトリBPの変化とかかわる行動的文脈 (behavioral context)が, ことのほか重要ということ になる，言うまでもなく、アンビュラトリ BP計測 の場合, こうした行動的文脈は, 実験室的状況と 異なって, あらかじめ明白なわけではないから,こ れをチェックする手立てが必要となるのである。

\section{行動日誌}

行動的文脈をチェックするもっとも一般的なや り方は, 被験者に行動日誌 (behavioral diary) を付け させることである.それは単に日誌と呼ばれること も多いが, 本評論では, アンビュラトリ BPが行動 的文脈から解釈されるという側面を強調する意味 で，行動日誌と呼ぶことにする，典型的には，ア ンビュラトリBP計測装置が作動するたびに, 行動 日誌の小冊子を 1 枚めくりながら, そのときの行動 をチェックさせるわけである. Fig. 2 には, マーク シート方式を採用した1例が示してある(Van Egeren \& Madarasmi, 1988)。この1枚は, 被験者が 簡単な事前指導を受ければ， 30 秒〜 45 秒でチェッ ク可能とされる。 また，実験者にとっては，その 
ままコンピュー夕に読み込み可能であるため, 集 計の手間が相当省ける. 実際, 15 分に 1 回の計測 であっても，かりに睡眠を 8 時間とすれば，1 日全 体で 64 枚分にも達する。なお，この例では，該当 するチェック項目が見つからない場合のために，自 由記述の可能な空白欄も用意されている.

Fig. 2 のような行動日誌を構成する場合，第 1 に 考えるべき重要な点は, 自身の研究目的を踏まえ， アンビュラトリ $\mathrm{BP}$ 計測と関連づけたい標的変数を 明確にすることである，また，攪乱要因となり得 る交絡変数についても，押さえておくことである. これら双方を盛り込むことで, 所期の目的にかなっ た，独自の行動日誌を作ることが肝要である (Gellman, Ironson, Schneiderman, Llabre, \& Spitzer, 1992).たとえば，自宅対職場のBP差に興味がある

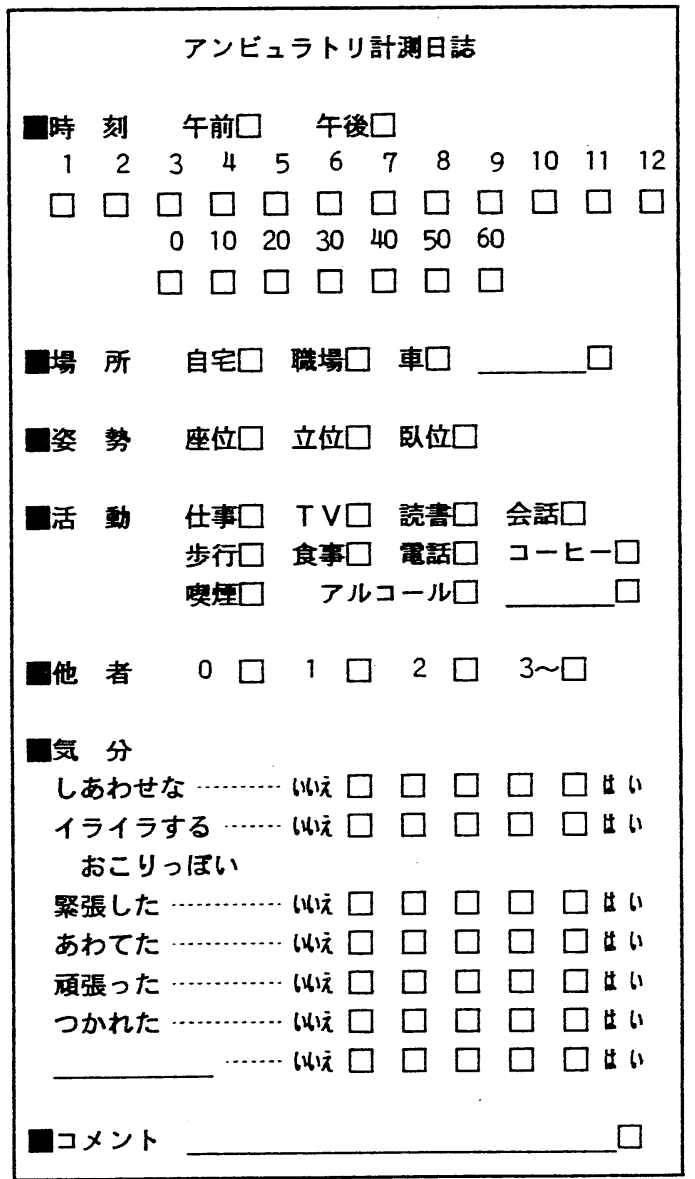

Fig 2 典型的な行動日誌の 1 例 (Van Egeren \& Madarasmi, 1988 から転載).
としたら，標的変数は当然ながら「場所」という ことになる。しかし，自宅ではもっぱら座位であ るのに，職場では立位が多いとしたら，自宅対職 場にBP差が出現したとしても，座位対立位の差が 紛れ込んでいる可能性は高い。そこで，少なくと も「姿勢」は，交絡変数として折り込む必要が出 てくる.

なお，行動日誌の記入間隔は，アンビュラトリ 計測する生理指標が何であり，行動的文脈で問題 となる標的変数が何であるかという点と，分かち 難く結びついている。しかし, 15 分を切るような 短い時間間隔で行動日誌をチェックさせるのは, 生 理指標と標的変数のいかんにかかわらず，無理が あるとされている (Harshfield, Hwang, Blank, \& Pickering, 1989). また，記入方法についても， Fig. 2 のような, いわば離散的なもの以外に, 連続的な ものも考えられる (Hedges, Krantz, Contrada, \& Rozanski, 1990).これは, 直前回の記入以後をすべ てカバーするように，遡及的に記録させるもので あるが，記入間隔が開くほど，不正確になる恐れ がある。ちなみに，ある特有な生理的変化パ夕ー ンを検知し，その都度行動日誌への記入を被験者 に催促するような，いわば賢いアンビュラトリ計 測装置の開発も考えられる。とく，連続 24 時間 にわたってアンビュラトリBPが1拍毎に計測され る場合は, 計測時点が記入の合図とはなり得ない から，こうした工夫も意味を持ってくる (Roffe, Bertram, \& Hunyor, 1985).

以上に述べたような行動日誌の特徵を一般的に 要約すれば，他の自己報告式ツールと異なり，自 然環境下で, かつ, 繰り返し記入されるというこ とである，そのため，他者による観察ではなかな かチェックできないものや(たとえば, 喫煙本数), まったくチェック不可能なもの(たとえば，気分の 移り変わり)まで含めて, 相当程度まで捕捉できる ことになり，行動的文脈を浮かび上がらせるのに 有効である。一方，短所としては，その主観的性 質のゆえに，記録の不正確さないし抜け落ち，と いったことが，常に懸念される．また，項目数が 増えたりすると，記入の手間がかかる分だけ，遵 守率の落ちる恐れもある. 行動日誌への記入法を 懇切丁寧に説明し, 正確に記入することの重要性 
を強調し，場合によっては正確な記入への報酬を 出すなど，それなりの工夫が必要となる(Chesney \& Ironson, 1989).

行動日誌は, いわゆる自己モニタの一種である が, それ故にまた, 特有の短所を内包することと なる.すなわち, 自らの行動をチェックすること は，その行動を変化させる方向に働く恐れがある。 実際, 標的行動に注目し始めると, それとかかわ る誘因性や構え・期待, ないし, 目標設定などが, その出現頻度を左右しかねないのである(Kazdin, 1974)。たとえば, 肥満者にとって, カロリーの高 い食べ物は負の誘因性を持つであろうから, 行動 日誌をつけ始める前と比べれば, この手のものを ロにしにくくなるであろう. 行動医学的治療法と しての自己モニタを議論する場合なら，その治療 機序をなすものとして評価できようが, アンビュ ラトリ心理生理学の立場からすれば, 行動的文脈 が不自然になることであり, 問題がある.

こうして，自己モニタが標的行動に及ぼす影響 は不可避であるから,アンビュラトリBPを行動日 誌と付き合わせる際は, この点をいつも念頭に置 く方がよい.もっとも，アンビュラトリ BP 計測装 置を装着すること自体が, 日常行動パターンを一 定程度変化させるといわれる (Blanchard, Cornish, Wittrock, \& Jaccard, 1990)，その意味で, 我われが 観測するのは, アンビュラトリ BP 計測装置を装着 したがために変化し，さらに，行動日誌をつけた がために重ねて変化した，ある程度まで不自然な 標的行動でしかない，ということにもなろう。

\section{体動計測}

行動的文脈をチェックするには，もう一つのや り方がある.すなわち, 体動を計測すること (actimetry)である.ここで, 体動とは, 姿勢や動作 (Fig. 2 の例でいえば,「活動」中の「歩行」)の変化に伴 う体の動きを指す. 大半のアンビュラトリ BP 研究 にあって, 体動は交絡変数であり, しかも, 周知 のごとく,アンビュラトリ BPを変動させる最大の 要因である。実際, Gellman, Spitzer, Ironson, Llabre, Saab, Pasin, Weidler, \& Schneiderman (1990) によれば，収縮期 BP の $33 \%$, 拡張期 BP の $47 \%$ は, 姿勢の変化だけで説明できるといわれる.もっ とも, 姿勢の変化には大抵動作の変化も伴うであ
ろうから, 両者を合わせた総体としての変化分と 見ておいた方がよいであろう。いずれにしろ，ア ンビュラトリBP計測における体動の重要性からし て, 行動日誌で定性的なチェックをするよりも, 定 量的な面まで含め, より客観的な技法によって体 動をチェックしようと試みるのは, 自然の成り行 きといえる。

体動計測装置は, Patterson, Krantz, Montgomery, Deuster, Hedges, \& Nebel (1993)によれば, 3 種類に分類可能である.すなわち, 第 1 は, 主要な 筋肉群 (たとえば, 太股)の収縮と関連する筋電図 を取り出し, 静止中対活動中を判別する技法. た だし，この技法では，姿勢の違いまでは分からな い. 次いで, 第 2 は, 身体の動きに感応する, 水銀 スイッチ変換器を用いたもの. しかし, 水銀スイッ チは, 体動が弱過ぎても強過ぎても感応しないた め, 体動の自己報告と突き合わせてみると, せい ぜい中等度の相関しか得られないという.さらに, 第 3 は, 小型の加速度計から成り, 体動の量と強度 が共に計測可能なもの. もっとも，このタイプの 中にも，体動の自己報告との相関がさほど高くな いものもある.

これら 3 種のうち, 心理生理学的なアンビュラト リ計測においてもっとも普通に用いられるのは, 第 3 タイプの加速度計によるものである (Bussmann, Tulen, van Herel, \& Stam, 1998; Fahrenberg, Foerster, Smeja, \& Müller, 1997; Middelkoop, Van Dam, Smilde-Van Den Doel, \& Van Dijk, 1997; Patterson et al., 1993; Shapiro \& Goldstein, 1998). 比較的一般 的なピエゾ抵抗型の場合, その DC 成分からは, ゆっくりした動作や地軸に対する姿勢の变化が評 価でき, $\mathrm{AC}$ 成分からは, センサの感受方向に沿っ た加速度が評価できる. 装着部位の問題は重要で あるが, 手首, くるぶし, 胴体の 3 箇所に装着させ て相互比較を試みた研究 (Middelkoop et al., 1997) によれば, 利き手の手首は体動の最大水準と関連性 が高いのに対し, 非利き手の手首は胴体の動きを ある程度捉え得る.また, くるぶしの動きは胴体 の動きとかかわりが強いことから，体の重心に近 い腰仙領域の代用として，エネルギー消費量を推 定するのに活用できる，という。

しかし, 加速度計による体動計測では, 身体活 
動の質が大雑把にしか把握できず，アーチファク トとの見分けもときとしてつきにくい，といった 問題点がある．たとえば，時計型の体動計である 通称アクチグラフ (Actigraph; Redmond \& Hegge, 1985) は, 装着の容易さからしばしば用いられるが (Shapiro \& Goldstein, 1998), TV ゲーム中や運転中 に, 激しく動いたかのようなスコアが出てしまう. あるいは, 運転中の振動などがカウントされて, 体 動と見分けがつかなくなる，などの点が懸念され ている．この種の難点を克服するには，身体の複 数䇢所に計測機器を装着させるとか (上述), 行動 日誌で補うとか, あるいは, 心拍数を同時に記録 する，といった手立てがあり得る．とくに，体動を もっともよく反映するのは酸素摄取量であり，こ れは心拍出量一したがって, 心拍数とおおむね並 行関係にあることから，心拍数の同時記録はこと のほか有意味，と考えられる，ただし，精神活動 の中には，能動的対処事態 (たとえば，暗算)のよ うに，そのときの体動をはるかに越えた，過剩な 心拍数反応の出現することもしばしばあるから (Turner, Carroll, Hanson, \& Sims, 1988), 心拍数を 体動の目安とするときは, 行動日誌を併用して, 精 神活動の中身を押さえておく必要があると思われ る.

以上, 加速度計を中心とした体動計測装置は, そ の客観的性質の故に，大いなる魅力を秘めている ものの，その強みが十分発揮される段階にまでは 至っていない，つまり，異なる活動を判別できる と同時に，それらの代謝欲求を推定できることが 理想的であるのに，現状はまだ相当に距離がある といった感を否めないのである。

\section{日内変動}

24 時間全体を通じたアンビュラトリBPのさまざ まな変動には, 覚醒対睡眠に対応した 2 相性のゆっ くりした変動が, 背景として乗っている (Fig. 1 参 照).これが概日リズムなのか, それとも, 日内変 動なのかは，意見の分かれるところである．前者 の言い方は, 体内時計など, 生体固有のリズムで BPが調節されている，との立場を背景とする。こ れに対し, 後者の言い方は, こうした可能性を否 定し, 1 日の大きな $\mathrm{BP}$ 変動の波は, 単なる覚醒と
睡眠の交代による，との立場を反映する。この問 題を論じるのに，行動日誌や体動計測のデー夕は さほど必要としないが, 生物的要因対行動的要因 のいずれが優位なのかをめぐる議論であることか ら，したがってまた，24 時間全体にわたる基調的 変動の解釈とかかわることから，ここで整頓して おくことにしよう。

Pickering グループ (Pickering, 1993; Pickering, Schwartz, \& Stone, 1996) は，それぞれの立場を, オッシレイター・モデル対セットポイント・モデ ルと名づけ，それぞれに予想される背景機序 (内因 性対外因性), 主決定因 (時間帯対活動ないし覚 醒), 位相転移への順応性 (遅延的対即時的), 変動 パターン (対称的対非対称的), コサイナー法の適 合度 (良好対不良)を, 対照させて示している.こ れらのうち，位相転移への順応性とは，睡眠から 覚醒(あるいは逆)への移行が, 通常の場合であれ, 交代勤務などの特殊な場合であれ，BPの急峻な上 昇 (下降)に伴われるか否か，を問題とする，その 傾向が弱ければ遅延的, 強ければ即時的, という わけである。また，変動パターン，および，コサ イナー法の適合度は, 相互に関連しており，24 時 間を通して見たアンビュラトリBPの変動パターン が振幅および時間経過の両面から見て対称的なも のに近ければ, 24 時間を単一の周期値とするコサ イン曲線の当てはめ(いわゆるコサイナー法によ る; Halberg, 1969)は，それだけ良好になるはずで ある。

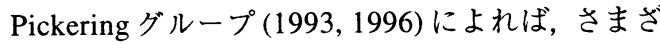
まな証拠からみて，24 時間全体にわたるアンビュ ラトリBPの変動は, オッシレイター・モデルによ るよりも，七ットポイント・モデルで説明できる 部分が多い。したがって，概日リズムというより も, 日内変動と見なす方がいっそう適切である，と いう。このこととの関連で，しばしば引き合いに 出されるのは, 24 時間アンビュラトリ BP記録を被 験者間で平均すると, 夜中に底を突いた BPは, 早 朝へかけて徐々に上昇する，典型的なパターンを 示す (Millar-Craig, Bishop, \& Raftery, 1978).しか し, 1 日の時間帯ではなく, 起床時間で合わせて平 均し直すと, 朝の BP 上昇ははるかに急峻な様相を 呈する (Floras, Jones, Johnston, Brooks, Hassan, \& 
Sleight, 1978)，という事実である。つまり， Millar-Craig et al. (1978)のデータで, 睡眠から覚醒 という位相転移への順応性が遅延的であるように 見えたのは, 起床時間の違いを無視して平均した ことによる，統計上の現象に過ぎない，実際のと ころは, Floras et al. (1978) から示唆されるよう に，即時的である可能性が強い，というわけであ る.

こうした，概日リズムなのか日内変動なのかと いった議論とは別に, 24 時間アンビュラトリBPの 周期構造を決定する技法についても，さまざまな ものが試みられてきている。この分野で伝統的に 使われてきた技法の中で，肉眼的臨床観察とも一 致した印象を与えやすいのが，上述のコサイナー 法である。実際，この技法では，アンビュラトリ BPデー夕に対して 24 時間を単一の周期とするコサ イン曲線を最小自乗法により当てはめ, 平均値, 変 動幅, 頂点位相という 3 つ組変数を決定して, その 日内変動を描き出そうとする。だが，現実の 24 時 間アンビュラトリBPが，単一の周期構造で理解で きるという保証はない. それに，単一の周期構造 でよいというのなら，凸型矩形曲線をもって近似 した方が，当てはまりはむしろよいとの報告もあ る (Idema, Gelsema, Wenting, Grashuis, van den Meiracker, Brouwer, \& Man in't Veld, 1992).

そこで, 24 時間全体にわたるアンビュラトリ BP は, 複雑な周期構造をしているとの前提に立ち, 一 般的な形で (単一周期構造の場合も含め) 解析する 方が賢明である。その意味で，もっとも一般的に 用いられてきたのが，高速 Fourier 変換である (Chau, Mallion, de Gaudemaris, Ruche, Siche, Pelen, \& Mathern, 1989; Staessen, Bulpitt, O’Brien, Cox, Fagard, Stanton, Thijs, Van Hulle, Vyncke, \& Amery, 1992).しかし，このスペクトル分析技法では，観 測された有限長の時系列データが過去にも未来に も繰り返し出現している，との非現実的な仮定を 置いている。 また，この延長部分の影響を打ち消 そうとして，空関数によるフィルタを導入するた め, 偽のスペクトル・ピーク (ゴースト)が出現し たり，スペクトルの分解能が低下する，つまり，周 期構造の決定にとっては，いささかやっかいな問 題が生じてしまうのである。その点, 観測された
有限長の時系列データだけを頼りに周期構造を決 定しようとする最大エントロピー法は，スペクト ルの分解能がきわめて高いことや，デー夕長が短 くても取り扱えることなど，多くの利点を持つと いわれている，今後，24時間アンビュラトリBPに も適用可能な新たなスペクトル分析技法として, 威 力を発揮するであろうと期待される (Ohtomo \& Tanaka, 1994; Sawada, Ohtomo, Tanaka, Tanaka, Yamakoshi, Terachi, Shimamoto, Nakagawa, Satoh, Kuroda, \& Iimura, 1997).

\section{生物行動的要因}

既述のごとく, アンビュラトリBPを分析するに は, 行動日誌や，ときには体動計測の結果と照ら し合わせながら, その変動が何を意味するのか探っ て行く必要がある。こうした照らし合わせは，大 別すれば，特定カテゴリー(たとえば，場所)の特 定オプション(たとえば, 自宅, 職場)，および，エ ピソード(たとえば，会話，TVゲーム)という，二 つの視点からなされてきた。

\section{カテゴリー/オプション分析}

アンビュラトリBPの変動が, 行動日誌の記載な どに基づき，ある特定カテゴリー(たとえば, 場所) について比較されるときは, 特定オプション (たと えば, 自宅, 職場) 間の平均水準が, 一般に検討の 対象とされる.カテゴリー/オプションの典型的な ものとしては,「場所/自宅, 職場」の他に,「姿勢/ 座位, 立位, 臥位」や「気分/陽性の, 陰性の」, あ るいは,「社会的状況 $/ 1$ 人, 家族と一緒, 友人と一 緒, 見知らぬ人と一緒」などが挙げられる。これ に対し，行動日誌の記載に依らない，別種の外的 基準に基づいたカテゴリー/オプションもあり得 る。たとえば，「不安/高，低」といった人格特性 や，「カフェイン/摂取, 非摄取」といった生活習 慣によって被験者を群分けし，2群間のアンビュラ トリ BP 平均水準を比較するといったやり方であ る.こうした場合は，この第 1 次的群分けのもと で,さらに「場所/自宅, 職場」と絡めて下位比較 のなされることも少なくない. その意味で, カテ ゴリーノオプションに基づいた分析は, きわめて適 用範囲の広いものといえる。なお，既述のごとく， 「姿勢/座位, 立位, 臥位」は, アンビュラトリ BP 
変動と関連づけたい標的変数というよりは，攪乱 要因をなす交絡変数として取り扱われることが多 w.

以下では, カテゴリー/オプションが行動日誌の 記載に依る場合と, 依らない場合の 2 種類につい て，それぞれ典型的な研究を取り上げる．先ずは， 前者に含まれる典型的な研究 (Gellman et al., 1990; Goldstein, Jamner, \& Shapiro, 1992; Schwartz, Warren, \& Pickering, 1994)の中から, Schneiderman グループの『アンビュラトリBPに対する姿勢, 場 所，および，気分の影響』(Gellman et al., 1990)を 検討してみよう。彼らの研究では, 130 名余の成人 男女が, 覚醒時のアンビュラトリBPをS S acelabs 5200 で 20 分毎に計測された。また, BPの計測毎 に, 行動日誌への記載を求められた. 行動日誌に 盛り込まれたカテゴリー/オプションは,「姿勢/臥 位, 座位, 立位, 歩行, その他」, 「場所/職場, 自 宅, レストラン, 車, 店, 教会, バス, その他」, 「気分/満足した，幸せな，微笑んだ，笑った，緊 張した, いらいらした, 混乱した, 怒った」, など であった。 なお, 同一のカテゴリーに属する複数 のオプションで, 計測回数が不足気味なものは, 除 外ないし新たなオプションへのまとめ直しがなさ れた。たとえば，気分カテゴリーは，「中性的(満 足した), 陽性の (幸せな, 微笑んだ), 陰性の(緊 張した, いらいらした, 混乱した, 怒った)」とい う, 新たなオプションでまとめられた。こうして, 最終的かつ典型的には,「場所/職場, 自宅」およ び「気分/中性的, 陽性の, 陰性の」とアンビュラ トリBPとの関連性が,「姿勢/座位, 立位」の違い を考慮に入れながら分析されることとなった。

その結果, 座位の場合, 収縮期 $\mathrm{BP} /$ 拡張期 $\mathrm{BP}$ と も, 場所については, 職場の方が自宅よりも高く 出ることが確かめられた (129/82 mmHg 対 124/78 $\mathrm{mmHg})$. 気分についても, 場所ほど明確な差では ないものの, 陰性および陽性の方が, 中性的なも のよりも有意に高く出ると判明した $(129 / 83$ $\mathrm{mmHg}, 128 / 84 \mathrm{mmHg}$ 対 125/81 $\mathrm{mmHg}$ ).これに対 し，立位の場合は，場所に関する収縮期 BPでのみ， 逆傾向の差 (自宅の方が職場より高い)を認めたも のの, 有意ではなかった.ささらに, 同一の被験者 群に関する結果を, 「社会的状況 / 1 人, 家族と一
緒, 友人と一緒, 見知らぬ人と一緒」というカテ ゴリーノオプションで分析した続編の報告 (Spitzer, Llabre, Ironson, Gellman, \& Schneiderman, 1992)に よると, 座位の場合, 収縮期 BP/拡張期 BP とも, 見 知らぬ人や友人と一緒である方が, 家族と一緒で あるよりも高く出ていた $(138 / 86 \mathrm{mmHg}, 128 / 81$ $\mathrm{mmHg}$ 対 $125 / 79 \mathrm{mmHg}$ ), 立位については, 同傾 向の差を認めたものの, 有意とはならなかった。ち なみに, 見知らぬ人や友人と一緒である場合, 家 族と一緒であるよりも会話の多いことが予想され， これがBP上昇に影響を及ほしたと思われるが，こ の点は扱われていない。

Schneiderman グループのまとめによれば，アン ビュラトリ BPに与える影響は, 収縮期 BP/拡張期 BPの被験者内分散に対する説明率でみた場合,「姿 勢/座位, 立位」が $33 \% / 47 \%$ と, 一貫して大き いと判明した。ただし，既述のごとく，姿勢の変 化は多くの場合動作の変化を伴うから, 両者を合 わせた総体としての変化分と見ておいた方がよい, とは言える. 次いで, 「社会的状況/家族と一緒, 見 知らぬ人と一緒; 座位」の $36 \% / 37 \%$, 「社会的状 況/家族と一緒, 友人と一緒; 座位」の $23 \% / 24 \%$ と続き,「場所/職場, 自宅; 座位」は $10 \% / 15 \%$ 程度,「気分/陽性の, 中性的; 座位」および「気分/ 陰性の, 中性的; 座位」はいずれも $6 \% / 8 \%$ 止まり であった。交絡变数としての姿勢は, 場所や気分 に対して，座位でのみ影響を及ほしたわけである。 この点については, 立位が座位と違い, 姿勢を支 えるための BP 上昇を少なからず必要とするため, その影響が場所や気分に強く重畳してしまったの であろう，と示唆されている。

続いて, カテゴリーノオプションが行動日誌の記 載に依らない典型的研究 (Green \& Suls, 1996; Light, Turner, \& Hinderliter, 1992; Shapiro, Goldstein, \& Jamner, 1996)の中から, Shapiro グループ の『黒人および白人学生における, 敵意, 怒り表 出, 不安, 並びに, 防衛のアンビュラトリBPに対す る影響』と題された研究を取り上げることにしよ う (Shapiro et al., 1996). 彼らの研究で用いられた のは, 人種 (黒人, 白人)および性別 (男性, 女性) を異にする140名余の学生であり, アンビュラトリ BPが覚醒時は 20 分毎に, また, 睡眠時は 1 時間ご 
とに，Accutracker II を用いて 24 時間計測された。 そして，覚醒時には，BPの計測毎に行動日誌への 記載を求められた，着目されたカテゴリー/オプ ションは,「敵意/高, 低」(Cook \& Medleyの敵意 尺度で評価),「怒り表出/高, 低」(Spielbergerの怒 り表出下位尺度で評価), 「不安/高, 低」(Taylor の顕現性不安尺度で評価) という 3 種類の人格特性 であり，いずれも「防衛/高, 低」(MarloweCrowneの社会的望ましさ尺度で評価) との組み合 わせで検討された。 また，この大枠のもとで，「人 種/白人，黒人」および「性/男性，女性」による 差が調べられた。さらに,「24 時間/覚醒時, 睡眠 時」が比較検討の対象とされた，最後者を別にす れば，あとはすべて行動日誌の記載を必要としな い, 別種の外的基準に基づいたカテゴリー/オプ ションであることが分かるであろう.

彼らの研究結果によれば，もっとも顕著に出た のは, 覚醒時の拡張期 BPにおける,「人種/白人,

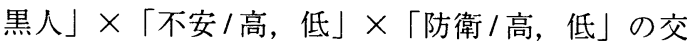
互作用であった。すなわち, 覚醒時の拡張期 BP は, 高不安かつ高防衛の黒人でとくに高い水準を示し た. 実際, このタイプの黒人では，覚醒時の拡張 期 BPが $78 \mathrm{mmHg}$ まで上昇していた。これに対し, 低不安な黒人, ないし，高不安ではあっても低防 衛な黒人では，せいぜい $70 \mathrm{mmHg}$ 程度の水準を示 したに過ぎなかった。ささらに, 白人では，不安と 防衛の高低にかかわらず, $70 \mathrm{mmHg}$ の水準に達し なかった．睡眠時の収縮期 BPについては，「人種

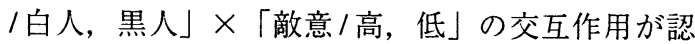
められ, 敵意の高い黒人では, 収縮期 BP が睡眠時 にさほど低下していないことも判明した。 なおここ うした人格特性での結果とは独立に，黒人は白人 に比べて, また, 男性は女性に比べて, 収縮期 BP/ 拡張期 BP とも高い水準を示した。 ちなみに，行動 日誌でみる限り，体動の影響はいずれの下位群で も同程度であったことから，この分析の範囲では 考慮しなくてよいと思われた。

Shapiro グループの研究は, 特定の生物行動的要 因が, 高血圧の心理生理学的危険因子としてどの 程度重要かを,アンビュラトリBPに対する寄与率 の面から評価し，その病因論的役割を探ろうとす るものである。また，上述の Schneiderman グルー
プの研究も，姿勢・場所・気分対アンビュラトリ BP とのかかわりを基礎的に調べながら，将来的に は同様の問題に切り込もうとしていた。これまで にも，黒人で高血圧の発症率が高いことや(Anderson, McNeilly, \& Myers, 1995), 閉経前の女性が心 臓血管系疾患にかかりにくいことは (Stoney, 1992)，繰り返し報告されてきたことであるから， 本研究の結果はこれらと矛盾しないものといえる. 興味深いのは，人種における差が，人格特性のい かんによって，さらに修飾されていた点であろう。 すなわち，敵意や，不安と防衛の重ね合わせが，人 種とかかわりながら，アンビュラトリ BPの出方に 影響を与えていたことである。もっとも，不安と 防衛の重站わせについては，むしろ低不安かつ 高防衛（いわゆる抑圧的対処）の方が，心臟血管系 反応が強く出るとの報告もあり (Weinberger, Schwartz, \& Davidson, 1979), 解釈のしにくい面が 残る、だが，総じて，アンビュラトリ BPに対する 心理生理学的接近法の典型的なものとして, 参考 にすべき点の多い研究といえよう.

\section{エピソード分析}

カテゴリー/オプション分析になぞらえて言え ば，エピソード分析は，「日常活動/エピソード $\mathrm{E}_{\mathrm{i}}$, その他」(i=1, 2, .., n ) という形を取る。つまり，大 カテゴリー「日常活動」のもとにまとめられた各 種の「エピソード $\mathrm{E}_{\mathrm{i}}$, その他」をオプション分析す る, 特殊なケースとみなされる。オプションとし ての「エピソード $\mathrm{E}_{\mathrm{i}}$ ，その他」は，すべて行動日 誌に盛り込まれるから，被験者はBP計測のたびに 該当する項目をチェックすればよい。一見して分 かるごとく，この分析法における興味の中心は，ア ンビュラトリ BPがばらつくもとになる主要なエピ ソードを，できるだけ詳細に知ることである。こ の分析法の長所は，オプションの中身がきわめて 具体的な点である。したがって，特定エピソード $\mathrm{E}_{\mathrm{k}}$ の, ベースライン (たとえば,リラックス時や睡 眠時) と比べた BP 反応性を評価することに，独自 の意味も出てくる．一般のカテゴリー/オプション 分析が，もっぱら平均水準を対象にするのとは，い ささか事情が異なる。

しかし，こうした特徵を持つエピソード分析は, さほど行われてきていない。アンビュラトリ BPが 
好んで活用されてきた，高血圧に関する発症過程・ 診断・治療・予後などの研究分野からすれば(「は じめに」の節を参照), 覚醒時と比べた睡眠時 BPの 下がりにくさなどといった，カテゴリー/オプショ ン分析から得られる情報の方が有益であったため かも知れない。あるいは，もっと一般的に，法則 定立的な陳述の成しやすいカテゴリー/オプション 分析と比べ，エピソード分析では現象記述的な側 面が強いためかも知れない。そこで，筆者の手元 にある数少ない関連論文 (Clark, Denby, Pregibon, Harshfield, Pickering, Blank, \& Laragh, 1987; Stephens, Crowther, Koss, \& Bolen, 1988; Van Egeren \& Sparrow, 1990) の中から, 以下では Pickering グループの『BP日内変動に対する活動お よび時間帯の効果とかかわる定量的分析』と題し た研究を取り上げることにしよう (Clark et al., 1987).

彼らの研究では, 中高年の男女軽症高血圧患者 460 名余 (少なくとも2 週間前から降圧剤の服用を 中止) が, 職場での仕事を有するか否かによって, 自宅下位群と職場十自宅下位群に分けられ，それ ぞれ Del Mar Avionics PIII アンビュラトリBP計を 装着されて，覚醒時は15 分毎に，また，睡眠時は 30 分毎に, 24 時間の計測を体験した。患者は, こ のルーチン計測に加えて, さまざまな活動の最中 に, 手動で BP計測をスタートさせるよう求められ た。そして，ルーチンであれ手動であれ，BP計測 の終了直後に, 行動日誌で「場所/自宅, 職場, そ の他」, および,「活動/仕事, 雑用, デスク・ワー ク, 着衣, 食事, 会合, 電話, 読書, リラックス, 買い物, 睡眠, 会話, 移動, $\mathrm{TV}$, 歩行, 書きもの」 をチェックした。ただし，本論文中に掲載された 16 種類の活動とかかわるオプションは, アンビュ ラトリBPの計測過程で少なくとも20名の患者に よってチェックされたものを，事後的に選別して 列挙したものであるとされることから，もともと の行動日誌に列挙されたリストとは異なると考え られる. ちなみに, 得られたデー夕の分析では, 患 者毎の平均的な BP 水準の違いを調整すべく, 診察 室での BPを統制変数とし, 活動ないし時間帯 (計 測時点を 1 時間単位でまとめて 24 点で表現)のア ンビュラトリ BPに対する影響を評価する, 共分散
分析型のモデルが用いられた。

その結果, 第 1 に, 活動および時間帯は, いずれ もアンビュラトリBPのバラツキを相当程度まで説 明できたが (説明率 $30 \%$ ４0\%), 活動の方がいっ そう高い説明率を示した．活動の中に睡眠という オプションの含まれていたことが，こうした結果 をもたらしたもの，と考えられた。ちなみに，活 動による影響を除去した残差のアンビュラトリ $\mathrm{BP}$ デー夕を描かせると，そこには時間帯による明瞭

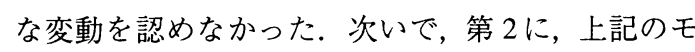
デルから推定された, 活動の各オプションにおけ る収縮期 BP / 拡張期 BP の上昇 $(\mathrm{mmHg})$ は, 職場 + 自宅下位群の場合,「リラックス; 職場, 自宅, その 他」をベースラインに採れば (論文中では絶対水準 が不明), 大きいものから順に,「会合; 職場」 (20.2/15.0)「仕事; 職場」(16.0/13.0), 「移動; そ の他」(14.0/9.2), 「歩行; 職場, 自宅, その他」(12.0 /5.5), 「着衣; 自宅」(11.5/9.7), 「雑用; 職場, 自 宅, その他」(10.7/6.7), 「電話; 職場, 自宅」(9.5/ 7.2), 「食事; 職場, 自宅, その他」(8.8/9.6), 「会 話; 職場, 自宅, その他」(6.7/6.7),「デスク・ワー ク ; 職場, 自宅, その他」(5.9/5.3), 「読書; 職場, 自宅」(1.9/2.2),「仕事; 自宅」(1.6/3.2),「TV; 自 宅」(0.3/1.1), であった. ちなみに,「睡眠; 自宅」 は -10.0/-7.6 mmHg と, 当然ながらマイナス方向 への変化を示した。これらに対し，自宅下位群の 場合は，類似の結果を示したものの，職場での活 動が含まれていない分だけ，BPの水準が低めに出 るなど, 内容に差が生じていた。なお，「活動/買 い物」および「活動/書きもの」に関するデー夕は, 自宅下位群にしか存在しないため,ここには示さ れていない.

Clark et al. (1987)のまとめによれば，第 1 の結果 に示されたように，「活動/睡眠 (対覚醒)」による 基本的な周期は認められるものの，これと独立な 日内変動は存在しないことが，あらためて支持さ れた。一方，第2の結果については，BP反応性の 個人差や気分の分析がなされなかった点を指摘す るだけにとどまっている，だが，こうした点との かかわりで言えば，「姿勢/座位，立位，その他」の 影響を評価していないことの方が，問題としては 重大であるように思われる。こうした問題点は別 
としても，本研究のやり方は，さまざまな活動に おけるべースライン (本研究ではリラックス時の BP) からみた BP 反応性のアンビュラトリな評価を 可能にすることから，実験室でのストレス刺激負 荷に対する反応性との比較検討に道を開くもので あり, 有効性が高いものと期待される.「BP反応性 の充進は将来の高血圧発症にとって危険因子の一 つである」との, いわゆる反応性仮説 (Pickering \& Gerin, 1990)の是非を論じるには，こうした意味で の実験室一日常生活関連性を調べることが, 欠くべ からざる一歩と思われるからである(澤田, 1998)． いずれにしろ，多様な活動がモデルに組み込まれ た好例として，注目に值する研究といえよう。

\section{今後へ向けて}

本評論では，アンビュラトリBPのバラッキが, 大は日内変動から小は個々の昇圧・降圧反応に至 るまで，実にさまざまな生物行動的要因によって 広範に影響される事実を，具体的な例なども交え ながら示した。 そのため, いくつかの典型的な研 究を引用するとともに, こうした影響の評価とか かわる研究の筋立ても追ってみた。 また, アンビュ ラトリBP 計測装置それ自体や, 行動日誌・体動計 測といった, 道具立ての問題にも検討吟味を加え てみた。

それにしても, アンビュラトリBP計測は一と くに, 心理生理学的視点からするそれは, 最近急 速に興味と関心が高まるようになった領域である. そのためか, 問題の立て方によって研究法は各種 各様であり, 確立されたものがあるようには見え ない。ささらに，我が国の心理生理学の分野におい ては,この種の研究はまだ始まったばかりである (澤田, 1997; 澤田・山越, 1995). 本評論では, こ うした現状を踏まえて, カテゴリー/オプションや エピソードといった, 簡潔ではあるが, 生物行動 的要因を扱うのに適した分析枠を試みに提示し，今 後の研究を進める手がかりを得ようとしたわけで ある。

ここで, アンビュラトリ計測の, これまでに述 べてこなかった部分で (BP以外も含め), 心理生理 学的に興味深いものをさらに三つほど紹介し, 今 後の研究展開に向けた指針を探ることとしょう。
その一つ目は, アンビュラトリ BPの血行力学的昇 圧機序とかかわるものである。 また, 二つ目は, 疑 似実験室的 (quasi-laboratory) セッティングにおけ る,アンビュラトリ計測の活用についてである。 そ して, 三つ目は, 日常生活場面でアンビュラトリ 計測することがとり分け有効な, 臨床的問題 (ただ し, 高血圧以外) が少なからず存在する点である.

さて，一つ目から論じよう。 いま,「平均 BP= 心拍出量 $\times$ 全末梢抵抗」であることに注目すれば, 平均 BPの上昇は, 心拍出量ないし全末梢抵抗の一 方または双方が増加することによって生じること が分かる，そこで, 心拍出量 $(1 / \mathrm{min})$ がアンビュラ トリに計測できれば, 全末梢抵抗 $(\mathrm{mmHg} / \mathrm{l} / \mathrm{min})$ も 「平均 BP/心拍出量」で換算できることになる。そ うすると, アンビュラトリ計測の場面で, 特定の エピソード毎に「平均 BP, 心拍出量, 全末梢抵抗」 の三つ組反応を得ることができ, 平均 BPの上昇が どのような血行力学的機序に依っていたのかを, 推 し量ることが可能となる。もっとも，一般のアン ビュラトリ BP 計測装置で, 平均 BPが直接得られ るものは少ないが, 既述のごとく「平均 $\mathrm{BP} \fallingdotseq$ 拡張 期 $\mathrm{BP}+($ 収縮期 $\mathrm{BP}$ - 拡張期 BP) / 3」であること から, 収縮期 BP と拡張期 BPが計測されていれば, 概算可能である.

実験室的には, 能動的対処事態 (たとえば, 暗算 や反応時間) がその典型であるように, 競争や挑戦 を求められ，情動的混乱を伴うようなストレス刺 激は, 主として心拍出量の増加から BP 上昇を招く ことが知られている. 同じく, 受動的対処事態 (た とえば，寒冷昇圧や鏡映描写) に代表されるよう な, 動きのとれないまま注目や監視を続けるといっ たストレス刺激では, おもに全末梢抵抗の増加で BP の上昇することが分かっている (Allen \& Crowell, 1989; 澤田, 1990; Sawada, 1993; Sherwood, Allen, Obrist, \& Langer, 1986) . 興味の持たれるの は, これと同一の機序が日常生活場面でも認めら れるか, ということであろう。上述のごとく、「平 均 BP, 心拍出量, 全末梢抵抗」の三つ組反応を得 るには, アンビュラトリ心拍出量計測装置が必要 であり，これは最近になっていくつか出回り始め た段階である (Willemsen, de Geus, Klaver, van Doornen, \& Carroll, 1996; Yamakoshi, Nakagawara, 
\& Tanaka, 1997)。したがってまた，日常生活場面 におけるアンビュラトリ三つ組反応は, 一部で報 告されているに過ぎない (澤田, 1997; 澤田・山越, 1995). 能動的対処対受動的対処による血行力学的 昇圧機序の違いは, 生物行動論的にみた高血圧発 症の問題ともかかわって議論されてきたことから (澤田, 1998), 日常生活場面で直接こうした点を吟 味できるアンビュラトリ計測の活用は, 今後の展 開が期待される領域といえよう.

次いで, 二つ目は, 疑似実験室的セッティング において，アンビュラトリ計測の活用が期待され る，という点についてである，先ず，疑似実験室 的セッティングとは, 日常生活場面ないし非実験 室的場面であるにもかかわらず，結果に影響する 諸要因をある程度まで統制可能な—したがって, 標的変数と交絡变数をある程度まで識別可能な状 況を指す．カテゴリー/オプションになぞらえて 例を挙げれば, 「大学の授業 / 講義, 試験」(Sausen, Lovallo, \& Pincomb, 1992)や「パラシュート降下/ 前日夜 18:00-21:00, 当日朝 7:30-9:00, 搭乗 15 分 -30 分前, 搭乗直前, 搭乗直後, 離陸時, 飛行高度 500 メートル, パラシュート降下開始直前, パラ シュートを開く直前, パラシュートを開いた直後, 着地前, 着地後」(Schedlowski \& Tewes, 1992)など が，これに当たる。こうした疑似実験室的セッティ ングで，限定的にアンビュラトリ計測を活用する ことは,きわめて適しているといえよう。なお,こ の種の計測にあっては，疑似実験室的であるとい う性質上, 行動日誌を必要としないが,「パラ シュート降下」の例では体動計測が補助的に用い られている.

「パラシュート降下」(Schedlowski \& Tewes, 1992)では, Epstein (1967)の言う不安抑制過程が成 立するのか否かが, 再検討されている. すなわち, パラシュート降下の前後に, 心拍数と呼吸数のア ンビュラトリ計測装置が熟練者と初心者に装着さ れ, 前者は後者に比べて, 生理的覚醒の方が心理 的恐怖に先行しやすく，しかも，二つとも低水準 を示すのかどうか, 調べられたわけである. 結果 は, Epsteinの仮説を支持しなかったが, この研究 の重要な点は, 従来の知見で欠落していたパラ シュート降下開始から着地までのデータが, 最新
のアンビュラトリ計測で入手できたことである. 一方,「大学の授業/講義, 試験」(Sausen et al., 1992)では，医学部生が普段の授業日と正規の試験 日に，直前一最中 - 直後の合計 $2 \sim 4$ 時間，BPおよ び心拍数をアンビュラトリ計測されている。この 研究の狙いは, できるだけ日常生活に近い状態で, 精神的ストレスとかかわる生理的反応を調べよう とした点にある。いわゆる, 生態学的妥当性の高 い実験を，計画したわけである，結果は，試験の 直前からストレスを予期した高い反応が出現し, こ

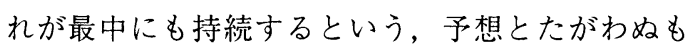
のであった. Sausen et al. (1992)の指摘によれば, 一般的な 24 時間アンビュラトリ計測を用いた研究 では, 被験者個々人の日常活動が違い過ぎるため, 精神的ストレスに対する生理的反応を調べようと しても，被験者間比較に困難を来す恐れがある。ま た，体動の影響を評価すべく行動日誌をつけさせ ても, 日誌をつけることが引き起こす反応性 (既 述)などを考慮しなければならない, という。確か に, 疑似実験室的セッティングでは, 検討対象と なるストレスの種類は特定のものに限られるもの の, こうした問題が生じにくく，それでいて，自 然環境下に近いデータが取れる，といった独自の 利点を有するといえよう。

さて, 最後の三つ目は, 日常生活場面でアンビュ ラトリ計測することがことの他有効な, 臨床的問 題が少なからず存在するという点についてである. その典型としてパニック発作を例に採ろう。この 疾患は, アメリカ精神医学会 (1987)の基準によれ ば，不安や恐怖の発作をその特徵とするが，著し い肉体的疲労や生命を脅かす状況がないにもかか わらず生じるものであり, また, 特定な恐怖刺激 の曝露によっては誘発されないものである. しか も, 呼吸困難, 失神, 頻脈, 震え, 発汗, 窒息感, 吐き気, 非現実感, 知覚異常, 悪寒, 胸部痛, 死 の恐怖，気が狂いそうなあるいは何かを仕出かし そうな恐怖，の内の少なくとも4つを伴うとされ る。疾病分類上は，いわゆる広場恐怖症（さまざま な人が行き交う，開かれた場所への恐怖のために， 自宅を離れたり，旅行に出たりすることができな い) と重複する部分が多い.こうしたパニック発作 の問題点は, 重症なケースでも大半は週にせいぜ 
い2 回程度しか発作を経験しないため, 実験室や診 察室での観察に適さないことである。したがって， 逆に, 実験室や診察室で, 意図的にパニック発作 を誘発する試みもなされているが, 生態学的妥当 性 (上述)の点で疑問が残る。こうして, 診断や治 療, ないし, 病因を探る上から, 当該患者のパニッ ク発作がどのような症状であるかをつぶさに知る には, アンビュラトリ計測が適していると理解さ れる。

それまではもっぱら患者の訴えに頼っていたこ の症状に関して，心拍数を標的反応としたアンビュ ラトリ計測で先駆けをなしたのは，Taylorグルー プであった (Taylor, Sheikh, Agras, Roth, Margraf, Ehlers, Maddock, \& Gossard, 1986; Taylor, Telch, \& Haavik, 1983). 1986 年の研究では, パニック発作 を訴える女性患者が，6日間にわたってアンビュラ トリ心拍数計測を連続実施され, 発作が起こった と感じたときや，予期不安を感じたときに，行動 日誌へ記入するよう求められた。 また, 体動計測 も同時に行われた，実験終了後に，先ずアンビュ ラトリ心拍数の記録だけが, 次いで, これを体動 記録と重ね合わせたものが，それぞれ専門家によっ て評価され，パニック発作の客観的な判定が下さ れた。これらを患者による行動日誌の記入結果と 付き合わせたところ，予期不安状況では心拍数に 増加を認めなかったが，パニック発作の自覚症状 がある場合は, その約 $2 / 3$ に明らかな心拍数の増 加を伴い, 併発症状 (上述のような精神身体的)の 多いケースほど見分けも容易であった，という。こ うして,パニック発作の訴えが，心拍数の顕著な 増加に伴われる事実を，この研究は明らかにした といえる。

以上, アンビュラトリ BP 計測という視点からは 外れたが, 心理生理学的にみて興味深い三つの話 題を, いささか詳しく紹介した. Turpin (1990) 流 に言うなら，全体をつらぬく縦系としての「アン ビュラトリ心理生理学」(ambulatory psychophysiology）に，改めて焦点を当てたかったからである. Turpin (1990) も指摘するごとく, 実験室ではまれに しか生じない, 実験室的セティングに合致しない, 自然的セティングに一般化できるか不安である, 実 験室の計測では標的反応が歪んでしまう, 治療効
果を評価したいなど，実に多くの場面でアンビュ ラトリ計測は威力を発揮すると期待される。冒頭 でも述べたが，日常生活場面で実施されるアンビュ ラトリ計測は, 特定の実験室的セッティングで行 われる短期間の計測よりも, 当該個人にとっていっ そう代表的なのである。この意味するものの重要 性が我われに実感されるとき，アンビュラトリ心 理生理学は多くの実りをもたらす, 新たな接近法 として立ち現れるはずである。やや遅ればせなが ら, 我が国でも, アンビュラトリ心理生理学の研 究が盛んになることを期待したい.

\section{引用文献}

Allen, M. T., \& Crowell, M. D. 1989 Patterns of autonomic response during laboratory stressors. Psychophysiology, 26, 603-615.

American Psychiatric Association 1987 Diagnostic and statistical manual of mental disorders (third ed., revised). Washington DC: American Psychiatric Association.

Anderson, N. B., McNeilly, M., \& Myers, H. 1995 A biopsychosocial model of race differences in vascular reactivity. In J. Blascovich \& E. S. Katkin (Eds.), Cardiovascular reactivity to psychological stress and disease. Washington DC: American Psychological Association. Pp.83-110.

Bevan, A. T., Honour, A. J., \& Scott, F. G. 1969 Direct arterial pressure recording in unrestricted man. Clinical Science, 36, 329-344.

Blanchard, E. B., Cornish, P. J., Wittrock, D. A., \& Jaccard, J. 1990 Effects of 24-hour ambulatory blood pressure monitoring on daily activities. Health Psychology, 9, 647-652.

Bussmann, J. B. J., Tulen, J. H. M., van Herel, E. C. G., \& Stam, H. J. 1998 Quantification of physical activities by means of ambulatory accelerometry: A validation study. Psychophysiology, 35, 488-496.

Chau, N. P., Mallion, J. M., de Gaudemaris, R., Ruche, E., Siche, J. P., Pelen, O., \& Mathern, G. 1989 Twentyfour-hour ambulatory blood pressure in shift workers. Circulation, 80, 341-347.

Chesney, M. A. 1984 Noninvasive ambulatory blood pressure monitoring. Proceedings of the Working Conference on Applicability of New Technology to Biobehavioral Research. Pp. 79-94.

Chesney, M. A., \& Ironson, G. H. 1989 Diaries in ambulatory monitoring. In N. Schneiderman, S. M. Weiss, \& P. G. Kaufmann (Eds.), Handbook of research methods in cardiovascular behavioral medicine. New York: Plenum Press. Pp.317-331.

Clark, L. A., Denby, L., Pregibon, D., Harshfield, G. A., Pickering, T. G., Blank, S., \& Laragh, J. H. 1987 A 
quantitative analysis of the effects of activity and time of day on the diurnal variations of blood pressure. Journal of Chronic Diseases, 40, 671-681.

Conway, J., \& Coats, A. 1989 Value of ambulatory blood pressure monitoring in clinical pharmacology. Journal of Hypertension, 7 (suppl 3), S29-S32.

Di Rienzo, M., Grassi, G., Pedotti, A., \& Mancia, G. 1983 Continuous versus intermittent blood pressure measurements in estimating 24-hour average blood pressure. Hypertension, 5, 264-269.

Epstein, S. 1967 Toward a unified theory of anxiety. In B. A. Maher (Ed.), Progress in experimental personality research (Vol. 4). New York: Academic. Pp.1-89.

Fahrenberg, J., Foerster, F., Smeja, M., \& Müller, W. 1997 Assessment of posture and motion by multichannel piezoresistive accelerometer recordings. Psychophysiology, 34, 607-612.

Floras, J. S., Jones, J. V., Johnston, J. A., Brooks, D. E., Hassan, M. O., \& Sleight, P. 1978 Arousal and the circadian rhythm of blood pressure. Clinical Science, 55, 395s-397s.

Gellman, M., Ironson, G., Schneiderman, N., Llabre, M., \& Spitzer, S. 1992 Sources of variability and methodological considerations in ambulatory blood pressure. In $\mathrm{T}$. F. H. Schmidt, B. T. Engel, \& G. Blümchen (Eds.), Temporal variations of the cardiovascular system. Berlin: Springer-Verlag. Pp.258-271.

Gellman, M., Spitzer, S., Ironson, G., Llabre, M., Saab, P., Pasin, R., Weidler, D., \& Schneiderman, N. 1990 Posture, place and mood effects on ambulatory monitoring. Psychophysiology, 27, 541-555.

Goldstein, I. B., Jamner, L. D., \& Shapiro, D. 1992 Ambulatory blood pressure and heart rate in healthy male paramedics during a workday and a nonworkday. Health Psychology, 11, 48-54.

Green, P. J., \& Suls, J. 1996 The effects of caffeine on ambulatory blood pressure, heart rate, and mood in coffee drinkers. Journal of Behavioral Medicine, 19, 111-128.

Groppelli, A., Omboni, S., Parati, G., \& Mancia, G. 1992 Evaluation of noninvasive blood pressure monitoring devices Spacelabs 90202 and 90207 versus resting and ambulatory 24-hour intra-arterial blood pressure. Hypertension, 20, 227-232.

Halberg, F. 1969 Chronobiology. Annual Review of Physiology, 31, 675-725.

Harshfield, G. A., Hwang, C., Blank, S. G., \& Pickering, T. G. 1989 Research technique for ambulatory blood pressure monitoring. In N. Schneiderman, S. M. Weiss, \& P. G. Kaufmann (Eds.), Handbook of research methods in cardiovascular behavioral medicine. New York: Plemun. Pp.293-309.

Hedges, S. M., Krantz, D. S., Contrada, R. J., \& Rozanski, A. R. 1990 Development of a diary for use with ambulatory monitoring of mood, activities, and physiological function. Journal of Psychopathology and Behavioral Assessment, 12, 203-217.
Idema, R. N., Gelsema, E. S., Wenting, G.-J., Grashuis, J. L., van den Meiracker, A. H., Brouwer, R. M. L., \& Man in't Veld, A. J. 1992 A new model for diurnal blood pressure profiling. Hypertension, 19, 595-605.

Kazdin, A. E. 1974 Reactive self-monitoring: The effects of response desirability, goal setting, and feedback. Journal of Consulting and Clinical Psychology, 42, 704-716.

Light, K. C., Turner, J. R., \& Hinderliter, A. L. 1992 Job strain and ambulatory work blood pressure in healthy young men and women. Hypertension, 20, 214-218.

Mancia, G., Omboni, S., \& Parati, G. 1997 Assessment of antihypertensive treatment by ambulatory blood pressure. Journal of Hypertension, 15 (Suppl), S43-S50.

Middelkoop, H. A. M., Van Dam, E. M., Smilde Van Den Doel, D. A., \& Van Dijk, G. 1997 45-hour continuous quintuple-site actimetry: Relations between trunk and limb movements and effects of circadian sleep-wake rhythmicity. Psychophysiology, 34, 199-203.

Miller, S. T., Elam, J. T., Graney, M. J., \& Applegate, W. B. 1992 Discrepancies in recording systolic blood pressure of elderly persons by ambulatory blood pressure monitor. American Journal of Hypertension, 5, 16-21.

Miller-Craig, M. W., Bishop, C. N., \& Raftery, E. B. 1978 Circadian variation of blood pressure. Lancet, ii, 795-797.

O'Brien, E., Atkins, N., \& Staessen, J. 1995 State of the market: A review of ambulatory blood pressure monitoring devices. Hypertension, 26, 835-842.

Ohtomo, N., \& Tanaka, Y. 1994 New method of time series analysis and "MemCalc." In K. Saito, A. Koyama, K. Yoneyama, Y. Sawada, \& N. Ohtomo (Eds.), A recent advance in time series analysis by maximum entropy method. Sapporo: Hokkaido University Press. Pp.11-29.

Parati, G., Pomidossi, G., Albini, F., Malaspina, D., \& Mancia, G. 1987 Relationship of 24-hour blood pressure mean and variability to severity of target-organ damage in hypertension. Journal of Hypertension, 5, 93-98.

Patterson, S. M., Krantz, D. S., Montgomery, L. C., Deuster, P. A., Hedges, S. M., \& Nebel, L. E. 1993 Automated physical activity monitoring: Validation and comparison with physiological and self-report measures. Psychophysiology, 30, 296-305.

Pickering, T. G. 1993 Applications of ambulatory blood pressure monitoring in behavioral medicine. Annals of Behavioral Medicine, 15, 26-32.

Pickering, T. G., \& Gerin, W. 1990 Cardiovascular reactivity in the laboratory and the role of behavioral factors in hypertension: A critical review. Annals of Behavioral Medicine, 12, 3-16.

Pickering, T. G., James, G. D., Boddie, C., Harshfield, G. A., Blank, S., \& Laragh, J. H. 1988 How common is white coat hypertension? Journal of the American Medical Association, 259, 225-228.

Pickering, T. G., Schwartz, J. E., \& Stone, A. 1996 Behavioral influences on diurnal blood pressure rhythms. Annals of the New York Academy of Sciences, 783, 132-140. 


\section{生理心理 17 巻 3 号 1999}

Redmond, D. P., \& Hegge, F. W. 1985 Observations on the design and specification of a wrist-worn human activity monitoring system. Behavior, Research Methods, Instruments, and Computers, 17, 659-669.

Richardson, D. W., Honour, A. J., Fenton, G. W., Stott, F. H., \& Pickering, G. W. 1964 Variations in arterial pressure throughout the day and night. Clinical Science, 26, 445-460.

Roffe, D. J., Bertram, C. D., \& Hunyor, S. N. 1985 Real time detection of significant blood pressure events in ambulant subjects. Clinical and Experimental Theory and Practice, A7 (2 \& 3), 299-307.

Sausen, K. P., Lovallo, W. R., \& Pincomb, G. A. 1992 Cardiovascular responses to occupational stress in male medical students: A paradigm for ambulatory monitoring studies. Health Psychology, 11, 55-60.

澤田幸展 1990 血圧反応性一仮説群の構築とその評 価一 心理学評論, 33, 209-238.

Sawada, Y. 1993 Reproducible increases in blood pressure during intermittent noise exposure: underlying haemodynamic mechanisms specific to passive coping. European Journal of Applied Physiology, 67, 367-374.

澤田幸展 1997 無拘束ホル夕型血圧一心拍出量計を用 いた日常生活場面における昇圧エピソードの解析 平成 $6 \cdot 7 \cdot 8$ 年度文部省科学研究費補助金 [一般研究 (C); 課題番号 06610084] 研究成果報告書

澤田幸展 1998 血圧反応性の六進は将来の高血圧発 症を予測できるか? 生理心理学と精神生理学, 16, 49-64.

Sawada, Y., Ohtomo, N., Tanaka, Y., Tanaka, G., Yamakoshi, K., Terachi, S., Shimamoto, K., Nakagawa, M., Satoh, S., Kuroda, S., \& Iimura, O. 1997 A new technique of time series analysis combining maximum entropy method and nonlinear least squares method: Its value in heart rate variability analysis. Biological and Medical Engineering and Computing, 35, 318-322.

澤田幸展・山越憲一 1995 実験室および日常生活にお ける循環動態調節の関連性 第 10 回生体・生理工学 シンポジウム論文集, 165-168.

Schedlowski, M., \& Tewes, U. 1992 Physiological arousal and perception of bodily state during parachute jumping. Psychophysiology, 29, 95-103.

Schwartz, J. E., Warren, K., \& Pickering, T. G. 1994 Mood, location and physical position as predictors of ambulatory blood pressure and heart rate: Application of multi-level random effects model. Annals of Behavioral Medicine, 16, 210-220.

Shapiro, D., \& Goldstein, I. B. 1998 Wrist actigraph measures of physical activity level and ambulatory blood pressure in healthy elderly persons. Psychophysiology, 35, 305-312.

Shapiro, D., \& Goldstein, I. B., \& Jamner, L. D. 1996 Effects of cynical hostility, anger out, anxiety, and defensiveness on ambulatory blood pressure in black and white college students. Psychosomatic Medicine, 58, 354-364.

Shapiro, D., Jamner, L. D., Lane, J. D., Light, K. C., Myrtek,
M., Sawada, Y., \& Steptoe, A. 1996 Blood pressure publication guidelines. Psychophysiology, 33, 1-12.

Sherwood, A., Allen, M. T., Obrist, P. A., \& Langer, A. W. 1986 Evaluation of beta-adrenergic influences on cardiovascular and metabolic adjustments to physical and psychological stress. Psychophysiology, 23, 89-104.

Spitzer, S. B., Llabre, M. M., Ironson, G. H., Gellman, M. D., \& Schneiderman, N. 1992 The influence of social situations on ambulatory blood pressure. Psychosomatic Medicine, 54, 79-86.

Staessen, J. A., Bulpitt, C. J., O'Brien, E., Cox, J., Fagard, R., Stanton, A., Thijs, L., Van Hulle, S., Vyncke, G., \& Amery, A. 1992 The diurnal blood pressure profile: A population study. American Journal of Hypertension, 5, 386-392.

Staessen, J. A., Fagard, R., Thijs, L., \& Amery, A. 1995 A consensus view on the technique of ambulatory blood pressure monitoring. Hypertension, 26 (part 1), 912-918.

Stephens, M. A. P., Crowther, J. H., Koss, P. G., \& Bolen, K. 1988 Effects of daily activities and social behavior on blood-pressure elevation. Journal of Behavioral Medicine, 11, 553-563.

Stoney, C. M. 1992 The role of reproductive hormones in cardiovascular and neuroendocrine function during behavioral stress. In J. R. Turner, A. Sherwood, \& K. C. Light (Eds.), Individual differences in cardiovascular response to stress. New York: Plenum. Pp.147-163.

Taylor, C. B., Sheikh, J., Agras, S., Roth, W. T., Margraf, J., Ehlers, A., Maddock, R. J., \& Gossard, D. 1986 Ambulatory heart rate changes in patients with panic attacks. American Journal of Psychiatry, 143, 478-482.

Taylor, C. B., Telch, M. J., \& Haavik, D. 1983 Ambulatory heart rate changes during panic attacks. Journal of Psychiatric Research, 17, 261-266.

栃久保 修 1988 血圧の測定法と臨床評価 メディ カルトリビューン

Turner, J. R., Carroll, D., Hanson, J., \& Sims, J. 1988 A comparison of additional heart rates during active psychological challenge calculated from upper body and lower body dynamic exercise. Psychophysiology, 25, 209-216.

Turpin, G. 1990 Ambulatory clinical psychophysiology: an introduction to techniques and methodological issues. Journal of Psychophysiology, 4, 299-304.

Van Egeren, L. F., \& Madarasmi, S. 1988 A computerassisted diary (CAD) for ambulatory blood pressure monitoring. American Journal of Hypertension, 1, 179S-185S.

Van Egeren, L. F., \& Sparrow, A. W. 1990 Ambulatory monitoring to assess real-life cardiovascular reactivity in Type A and Type B subjects. Psychosomatic Medicine, 52, 297-306.

Weinberger, D. A., Schwartz, G. E., \& Davidson, R. J. 1979 Low anxious, high anxious, and repressive coping styles: Psychometric patterns and behavioral and physiological responses to stress. Journal of Abnormal Psychology, 88, 369-380.

West, J. N. W., Townend, J. N., Davies, P., Sheridan, J. J., 
Stallard, T. J., Davies, M. K., \& Littler, W. A. 1991 Effects of unrestricted activity on accuracy of ambulatory blood pressure measurement. Hypertension, 18, 593-597.

White, W. B., Berson, A. S., Robbins, C., Jamieson, M. J., Prisant, L. M., Roccella, E., \& Sheps, S. G. 1993 National standard for measurement of resting and ambulatory sphygmomanometers. Hypertension, 21, 504-509. Willemsen, G. H. M., de Geus, E. J. C., Klaver, C. H. A. M., van Doornen, L. J. P., \& Carroll, D. 1996 Ambulatory monitoring of the impedance cardiogram. Psychophysiology, 33, 184-193.

Yamakoshi, K., Nakagawara, M., \& Tanaka, S. 1997 Recent advances in non-invasive ambulatory monitoring of cardiovascular haemodynamic parameters. Biocybernetics and Biomedical Engineering, 17, 181-202. 